\title{
Local Labour System After the Turn of the Millennium in Hungary
}

\author{
János Pénzes The current research puts the issue of functional \\ University of Debrecen \\ E-mail: \\ penzes.janos@science.unideb.hu \\ urban regions (or districts) into the focus \\ delimited by the commuting network of \\ employees. The local labour system (LLS) \\ provided a specific dimension of this complex \\ approach however it is one of the most adequate \\ Ernö Molnár \\ University of Debrecen \\ possibilities to delineate these areas of \\ commuting. The delimitation process consisted \\ of two steps with the separation of employment \\ centres and with the assignment of settlements to \\ molnar.erno@unideb.hu \\ these cores. The alteration of the LLS pattern was \\ also analysed as the investigation was carried out \\ by the census data from 2001 and 2011. The \\ Gábor Pálóczi \\ University of Debrecen \\ E-mail: \\ paloczig@gmail.com \\ results provided a comprehensive overview about \\ the process of territorial concentration and the \\ instability of peripheral areas. Significant regional \\ disparities of commuting came to light as the \\ consequence of the body of settlement network. \\ The territorial division of the country provided by \\ LLS pattern is fitting to the new and integrated \\ European approach of cities and their hinterlands \\ but it is not alternative against other \\ administrative or statistical divisions of Hungary. \\ However this territorial point of view is in closer \\ Keywords: relation to the issues of analysing the local labour \\ employment, market processes or the developments targeting \\ functional urban area, \\ the increase in employment. \\ commuting, \\ LLS, \\ settlement network
}




\section{Introduction}

In our approach, the Local Labour System (LLS) is a dimension of the delimitation of functional urban regions, which are recently receiving attention increased. The concept of functional urban regions can be traced back to the fundamental consideration that the operation and development of different territorial units can only be successful with the integrated management of cities and their hinterlands (EU 2011).

In Hungary, regionalisation integrates functional aspects (for example educational or medical services) and is implemented on various regional levels, mainly with the objective of developing administrative units (Barancsuk-Gyapay-Szalkai 2013). In the period between the two world wars, based on the uniformity of traffic connections and agricultural production, a landscape classification was prepared in the framework of the landscape administrative theory combining physical and human geography (Hajdú 2001). The 'product' of the period after the Second World War is 'economic region research', which attempted to delimitate units held together by 'organic economic relations' on the basis of production relations and territorial division of labour. At the same time, only a few representatives of these investigations (Gyula Krajkó in Southern Great Plain and József Tóth in Southern Transdanubia) deal with the level of the micro-districts that correspond suburban relations (Beluszky-Sikos 1982). The third approach is based on the central places theory. In this approach, the ideas of county towns establishing administrative units connected by 'real common interests and solidarity' corresponding to the catchment areas of towns and considering market towns and their scattered farmsteads as a pattern are popular (Hajdú 2001).

The other aspects formulated in connection with functional cohesion and establishment of administrative units (proportionality in territorial terms and in population number, full coverage of the country's territory, assigning each settlement to one centre) are in conflict with each other. This conflict can be associated with the different nature of the spatial organizational mechanism of regionalism and regionalisation (Süli-Zakar 2010). The nodal or functional regions of regionalism are characterised by elastic borders changing in time, which partly overlap and leave some uncovered areas (as opposed to the rigid and clear spatial frames of the administrative regions characteristic of regionalisation). Furthermore, due to the heterogeneity and differentiation of the settlement network, functional units of very different size may develop (Barancsuk-Gyapay-Szalkai 2013).

The aim of this study is the delimitation of districts based on the attraction of the labour market, which is one of the most important spatial organizational features of functional urban regions in Hungary after the turn of the millennium. However, as opposed to the characteristics of functional spatial structuring and acknowledging that the internal cohesion of spatial units delimited this way is based on relationships

Regional Statistics, Vol 5, No 2. 2015: 62-81; DOI: 10.15196/RS05204 
of varying intensity, we cover the country as a whole without duplications. On the other hand, we wanted to keep the temporal elasticity of nodal regions in mind. Therefore, we prepared the delimitation for two different dates. The investigation is based on the 2001 and 2011 census data on employment and commuting, ${ }^{1}$ which is supported by a number of considerations:

- Spatial mobility connected to employment is one of the strongest spatial structure-forming factors and an important aspect of delimitation of the catchment areas of settlements: the most regular and considerable personal relationship between employment centres and their surrounding settlements is the work commute (Radvánszki-Sütő (2007) and Bujdosó (2009)). Furthermore, the daily mobility for employment purposes and crossing borders of settlements has strengthened in recent decades: $30 \%$ and $34 \%$ of employees commuted to work in Hungary in 2001 and 2011, respectively.

- Censuses collect data on employment and daily commuting for work purposes with a unified methodological background that is also harmonized internationally. This enables the easy quantification of the intensity of intermunicipal relations.

However, before describing our empirical investigations in detail, we give a short review of the international and domestic regional delimitations on the basis of labour commuting. Our aim is not only presenting the importance of the applied indicator in international practice, but, by outlining the domestic preliminaries, to inform the starting points and methodological bases of our own study.

\section{Approaches of territorial division based on labour commuting}

The concept of functional urban regions dates back to the 1950s in the United States (Keserú 2013). Despite its long history, the concept is not clearly defined (OECD (2002) and Antikainen (2005)). On one hand, this lack of definition is due to the variety of statistical databases; on the other hand, the lack of definition is also due to the different settlement structure of countries (Keserú 2013). In the course of

\footnotetext{
${ }^{1}$ The most important source of employment and commuting data covering the whole country on settlement scale is the census. Our study is based on census data, but it is worth drawing the attention to some of their limits. The methodology of measuring the number of employed has changed since the 1990 census, so today, in line with international recommendations, employed are those persons aged 15 years and over who, during the week preceding the reference date of the census worked at least one hour for pay or profit or had a job from which they were only temporarily absent. Among others, people in work for public benefit and public work are classified as employed as well (for further details of methodology see. http://www.ksh.hu/nepszamlalas/docs/modszertan.pdf). Employment or commuting to work data may be biased of course by the grey or black economy, but we had no opportunity to correct these. In case of commuting data, a further problem is the category of those who 'work in different settlements, as in the applied methodology, we could not clearly assign this group to one commuting target settlement. Therefore, we had to disregard these data. The scope of our study was Hungary, so we did not examine employment abroad.
} 
delimitations, the 'quality' of centres (their size, and role in employment and institutional supply) and the specific features of the spatial flows and interactions organising the region must be taken into account. The real spatial organisational character of the city centre and the mutual relation system between the city and its region are essential for the creation of such a region (Klapka-Halás-Tonev 2013). In the course of its delimitation, commuting to work is taken as the basis for assigning the settlement to the centre where most people go to work (without a minimum threshold), but the urban character of the centre is emphasised by taking into account the existence of 15-20,000 employees (Drobne et al. 2010).

In many countries, functional regions form the basis for analysing socio-economic and labour market trends and social inequalities or the frame of delimitating underdeveloped regions in need of support (OECD 2002). ${ }^{2}$

The concept of functional regions is complex as it refers to regions where intense economic interactions, including the use of services, trade or commuting to work are typical (Karlsson-Olsson 2006). Despite this, in the course of the delimitation, most studies were mainly based on commuting for work purposes (Cörvers-HensenBongaerts 2009). Functional regions can be divided into further subgroups according to the direction of the commute (Klapka-Halás-Tonev 2013). In the OECD delimitation, functional regions were separated only in the narrower surroundings of cities with a population greater than 100,000, highlighting the large population density (OECD 2012).

As a part of the ESPON 1.1.1 project launched under the aegis of the European Commission, the concept of functional urban regions, which can be identified by the travel-to-work areas, is described. The essence of the delimitation method is that settlements are assigned to the centre to where the highest proportion of employees are commuting, exceeding a defined threshold within the employed (most often 15-20\%) (Antikainen 2005). As a consequence of this filter condition, the concept of functional urban areas is interpreted in a broader sense (Drobne et al. 2010). However, several thresholds may be fixed during the course of delimitation, including the minimum number of workplaces or the proportion of local employees in the area; these could also be changed depending on the population number. It is important to highlight that the thresholds may vary in different countries, and that there are a variety of alternative approaches (Cörvers-Hensen-Bongaerts 2009).

In addition to the term "travel-to-work area," "Local Labour Market Area" is also often used in the scientific literature. The conceptual difference between the two is

\footnotetext{
2 Connected to the concept of functional urban regions, it is worth mentioning that a Hungarian study was published in 1978, which delimitated 23 functional urban regions - in addition to Budapest and the today's county seats, Dunaújváros, Nagykanizsa, Sopron, as well as Baja, Kazincbarcika and Ózd were among the cetnres (LackóEnyedi-Kőszegfalvi 1978). Delimitations based mainly on commuting relations assigned each settlement to a single centre and kept also the hierarchical scheme of the National Spatial Development Concept of 1971 in mind.
}

Regional Statistics, Vol 5, No 2. 2015: 62-81; DOI: 10.15196/RS05204 
that in the former, weekly movements for work purposes are also included. The latter basically refers to daily commuting and does not necessarily take into account only the flow to a particular centre (Klapka-Halás-Tonev 2013). The common feature of these delimitations is that they cover regions that have intense relations, and depending on regional characteristics, significant areas may fall outside the created zones.

The defined thresholds constrain the adaptation of the international methodology presented. If the centres were designated by 20,000 employed persons, there would be 22 urban centres according to the 2011 data. In case of a lower threshold $(15,000$ employed persons), the number of centres would be only 32, that is, even Salgótarján would not fit into the narrower circle. According to the criterion of 100,000 inhabitants drawn for functional regions, in Hungary, only the capital, the regional centres, and Nyíregyháza and Kecskemét could be centres. Other approaches had to be rejected as not every settlement was assigned to the employment catchment area of a centre.

As a part of the RePUS (Regional Polycentric Urban System) project, the colleagues of VÁTI (Hungarian Nonprofit Ltd. for Regional Development and Town Planning) delimitate local labour market systems, also known as Local Labour System (LLS), by using the commuting for work data of the 2001 census (Radvánszki-Sütó 2007). As a continuation of the investigation, they combine the created catchment areas with the micro-regional system, which results in the establishment of territorial units called Functional Urban Districts (Sütő 2008). Without striving for completeness, from the domestic scientific literature in recent years, we would like to mention the study of Albert Faluvégi delimitating 'functional regions' on the basis of commuting data (Faluvégi 2008). These two domestic studies analyse the same database using a two-stage model where the centres were assigned first, and then the catchment areas were identified. The two authors of VÁTI took a much smaller critical mass (1,000 persons) as the basis for defining employment centres, but required the connection of at least one settlement attracted in the first place. The second approach only used absolute weights for the calculation: it considered urban employment centres as those with over 5,000 persons, and rural employment centres as those with between 1,200 and 5,000 persons. After delimitating the catchment area, every settlement is assigned to an employment centre in the first study, while in the second one, by fixing the critical degree of catchment, a number of settlements not belonging to any functional region remained in the system.

We prepared our work by modifying the methodology used by authors RadvánszkiSütő (2007), as we consider its practice of assigning centres embedded in the settlement network more flexible and better adaptable to the heterogeneity of the settlement system. Moreover, the delimitation of catchment areas in this study enables the consideration of the entire territory of the country without duplications. These methodological corrections will be discussed in the relevant parts of our study.

Regional Statistics, Vol 5, No 2. 2015: 62-81; DOI: 10.15196/RS05204 
Although the scope of concepts and approaches reviewed here is not complete and cannot always be clearly separated from each other, our 'brief investigation' well expresses the complexity of the problem and confirms the relevance of labour market studies.

\section{The phenomenon of commuting for work purposes and its research in Hungary}

In Hungary, by the progress of occupational re-stratification, commuting for work purposes became a mass phenomenon in the 1960s. On the one hand, the labour released from agriculture due to its large-scale reorganization and modernization and the concentrated industrial developments offering alternatives in terms of employment, and, on the other hand the development of public and individual transport provided the background of this process.

By the 1980s, commuting zones evolved, especially in the surroundings of settlements of town rank, which largely depended also on geographical characteristics: the (economic) size, density, and distance of the settlement (Erdôsi 1985).

Table 1

Number and proportion of employees commuting from their place of residence

\begin{tabular}{|c|c|c|c|c|c|c|}
\hline \multirow[t]{2}{*}{ Regions } & \multicolumn{3}{|c|}{$\begin{array}{l}\text { Number of employees } \\
\text { commuting from their place of } \\
\text { residence, thousand persons }\end{array}$} & \multicolumn{3}{|c|}{$\begin{array}{l}\text { Proportion of employees } \\
\text { commuting from their place of } \\
\text { residence, } \%\end{array}$} \\
\hline & 1990 & 2001 & 2011 & 1990 & 2001 & 2011 \\
\hline Central Transdanubia & 166.8 & 180.5 & 206.8 & 33.1 & 40.4 & 45.4 \\
\hline Western Transdanubia & 131.6 & 147.6 & 177.6 & 29.2 & 35.5 & 41.5 \\
\hline Central Hungary & 267.0 & 300.1 & 388.0 & 19.9 & 25.9 & 30.4 \\
\hline Southern Great Plain & 104.0 & 99.1 & 123.5 & 17.3 & 21.0 & 25.0 \\
\hline Northern Great Plain & 146.0 & 120.7 & 158.6 & 23.1 & 25.9 & 30.0 \\
\hline Southern Transdanubia & 129.2 & 106.8 & 116.6 & 29.6 & 31.7 & 34.0 \\
\hline Northern Hungary & 201.1 & 146.5 & 169.8 & 36.0 & 37.4 & 40.8 \\
\hline Country, total & $1,145.6$ & $1,102.0$ & $1,340.8$ & 25.3 & 29.9 & 34.0 \\
\hline
\end{tabular}

Following the regime change, the number of commuters decreased nationwide - the rate of decline was 3.8\% between 1990 and 2001 - but its exact trend within the decade is not known. The number of commuting employees was 1,145,581 in 1990, which fell to 1,102,005 by 2001 (while their proportion within all people employed increased from $25.3 \%$ to $29.9 \%$ ) (Table 1 ).

However, the change had distinctive regional differences: the number of employed people and commuters decreased mainly in the underdeveloped regions (at the same time, their proportion increased moderately in all regions). The drop in the number

Regional Statistics, Vol 5, No 2. 2015: 62-81; DOI: 10.15196/RS05204 
of commuters was larger in the less developed regions, which was due to the considerable regression of industry and mining employing a large number of commuters. Besides, the sharp rise of travel costs also reduced the chances of commuting (Szabó 1998). The change negatively affected the low-skilled social groups and the Roma (Kertesi (2000) and Pásztor-Pénzes (2012)). All these factors had serious regional-settlement structural consequences as well (Forray-Híves 2009): in case of small settlements farther away from the employment centres that have a low-skilled workforce, labour market problems accumulated (Balcsók 2000).

In 2011, 1,340,831 commuters were recorded during the census, which constitutes $34.0 \%$ of the people employed (however, more than one tenth of commuters 153,410 persons - commuted to varying settlements; so it was not possible to clearly identify the directions of their mobility). It is not incidental that in the underdeveloped areas, the low base value of the number of employed may also result in the relative high proportion of commuting. The detailed analysis of the trend of changes between 2001 and 2011 would exhaust the scope of this study. Moreover, the census data used are not very suitable to investigate the considerable decline of employment from 2008 to 2009 due to the economic crisis (Kiss 2011) and its effects on commuting. However, our analysis based on the comparison of the conditions on two dates (2001, 2011) has some dynamic elements.

Figure 1

\section{Change in the intensity of commuting between 2001 and 2011}

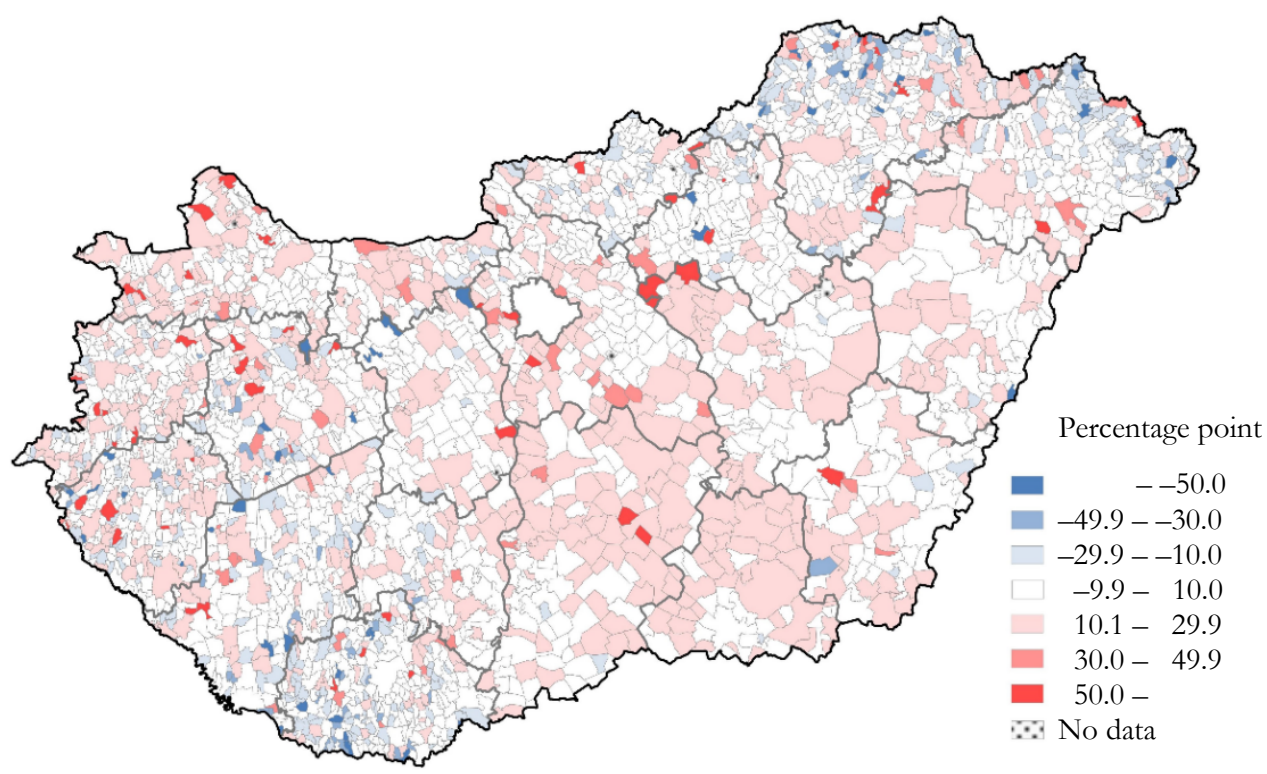

Regional Statistics, Vol 5, No 2. 2015: 62-81; DOI: 10.15196/RS05204 


\section{Intensity of commuting in 2011}

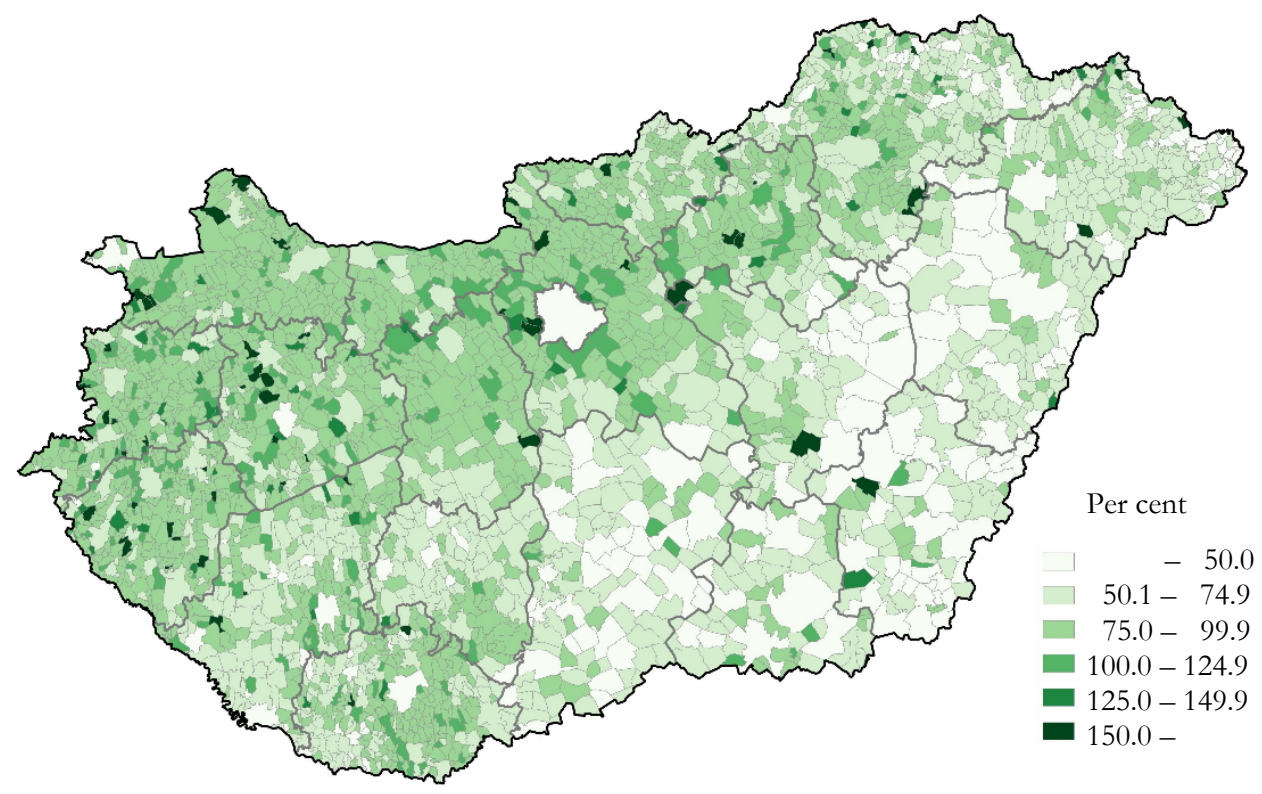

In our investigation, the frequency of movements for the purpose of work crossing settlement borders is essential: in regions that can be characterized with more intense relations, more pronounced local labour systems are delimitated. We summarize the settlement-level trends in the intensity of commuting in the last decade on two maps: in case of each settlement, the sum of the number of employees commuting from and to was compared to the number of resident employees and expressed as a percentage (although the method is not suitable for examining the labour force account and for accurately presenting the proportion of employees commuting from and to the settlement, it expresses the intensity of inter-municipal relations comprehensively, as it shows cross-commuting as well). The first figure shows the direction of changes between 2001 and 2011 (Figure 1). The importance of labour force movement crossing settlement borders is generally increasing, but its degree is outstanding in some distinguished settlements (for example, Budaörs, Dunakiliti, Dunavarsány, Jászárokszállás, Jászfényszaru, Mosonszolnok, Rácalmás, Sopronkövesd, and Tiszaújváros), because of the sharp increase in the number of people commuting to the settlement. In the case of these settlements, with the exception of only Budaörs, the workforce attracting effect of some significant industrial investments is in the background. The range of the strongly declining settlements is remarkable as well: one type is represented by previously significant, typically mining-related economic actors (for example, Balinka, Fenyőfó, Mány, Pusztavám, and Visonta). Their other basic type is connected to the north-eastern and south-western small village peripheries of the country and

Regional Statistics, Vol 5, No 2. 2015: 62-81; DOI: 10.15196/RS05204 
reveals the demographic degradation and socio-economic exclusion of these settlements (Kovács 2010).

The second figure shows the conditions in 2011, and outlines the pattern of differences in the labour force movement crossing settlement borders by large regions plastic. On the one hand, the differences that result from the settlement structure between the Great Plain, where local employment is stronger, and the Transdanubian and Northern Hungarian regions, which have a more fragmented structure with more intense relations, are clearly shown. On the other hand, by comparing the small village regions of Southern Transdanubia and Western Transdanubia, the differences which can be traced back to the difference in economic background are striking as well. Here, the intensity of commuting is a factor that indicates economic prosperity: the appearance of villages characterized by more intense relations shows some coincidence with the spatial structure of re-industrialization (Figure 2). Therefore, it is not surprising that, due to its indirect socio-economic effects, the phenomenon of commuting is also an important element of typifying settlements on a regional scale (Beluszky-Sikos 2007). The main lesson of the figure is that it is not possible to delimitate functional urban regions with internal relations of similar intensity that cover the whole territory of the country on the basis of commuting.

The role of labour commuting (defined as a production relationship closely connected to the specific production activity) in forming catchment areas has been questioned by several researchers (for example, Mendöl (1963) and Beluszky (1967)). However, due to the very narrowly available databases describing inter-municipal relations, labour commuting is considered in most catchment area studies (Timár 1983) and regional delimitations, or the need for it arises (Szalkai 2012). It is worth mentioning that the examination of the flows, especially road traffic, plays a more prominent role in the study of inter-municipal relations (for example, Szalkai (2010) and Tóth (2013a-b)), but the database built from surveying commuting for work during the census, which can be identified on the level of the settlement, offers broader opportunities for analysis as it also covers specific inter-municipal relations. Of course, functional catchment areas can be interpreted in a complex way by integrating a number of factors (for example, Beluszky (1967), Dövényi (1977), Bujdosó (2009), and Bodor-Pénzes (2012)). Therefore, the results of this study cannot be considered as an alternative system to complex catchment area studies or any other horizontal regional delimitation integrating several aspects. Despite this, we can refer to analyses which took commuting for work purposes as a basis for the dynamic examination of catchment areas (Erdősi (1985) and Nagy (1988)) or for establishing regional categories (Radvánszki-Sütő (2007) and Pénzes (2013)).

The investigation of employment centres also takes into account the characteristics of commuting in many cases for a given group of settlements (Balcsók-Koncz (2004), Molnár-Pénzes (2005), and Faluvégi (2008)).

Since the scope of commuting is narrowed considerably due to the costs of travel, the study usually applies at the level of labour districts, most likely in the direction of the local employment centre (Kertesi-Köllő (1998) and Pénzes (2013)). Contracted 
travel services ensured by larger employers may broaden the scope of commuting. At the same time, it is worth mentioning that this kind of delimitation cannot separately handle those who are commuting farther away and often, and not necessarily on a daily basis. In addition, employees commuting from the centres (mostly employees with more qualifications and larger scope) are largely outside the focus of the investigation.

\section{Employment centres and commuting districts}

We built our study by modifying the methods in the scientific literature according to our own criteria (Radvánszki-Sütó 2007). We carry out the delimitation that had been completed by 2001 again. We used a two-stage model to determine the commuting catchment areas.

First, the range of the centres was selected:

- We have taken all settlements with more than 1,000 persons employed locally ${ }^{3}$ (328 settlements in 2001 and 348 in 2011) into account. The threshold used the same as that used in the above mentioned literature.

- We left only those settlements among the centres that attracted at least one settlement from where the most commuters went to work in the given centre (205 settlements in 2001 and 197 in 2011). This selection method was also used based on the sources read previously.

- Next, we removed those settlements from the range of centres from where more than $10 \%$ of employees commuted to another centre (our earlier review of scientific literature includes similar thresholds). Although the threshold is arbitrary, we found it to be suitable to filter the range of employment centres (if $10 \%$ of a settlement's employed people commute to a single place, it means an external attachment which is strong enough to question that the settlement is an independent centre). In order to reduce the anomalies resulting from the application of the method, we have made an exception in two cases. On the one hand, in case of some settlements mutually attracting each other, centrepairs have been designated (Keszthely and Hévíz (2001), Keszthely and Hévíz (2011), Balatonboglár and Balatonlelle (2001), Balatonboglár and Balatonlelle (2011), and Siklós and Harkány (2001)). On the other hand, in the surroundings of larger towns, the settlements from where the proportion of people commuting was less than $20 \%$, the number of people employed locally was more than 5,000 (also called urban centres- Faluvegi (2008)), and there was a daily labour force account were considered independent centres, despite gravitating towards larger centres. In the surroundings of Budapest, Vác met

${ }^{3}$ In the study, 'people employed locally' are those who live and work in the settlement and those who commute to the settlement to work, that is, the number of people actually employed in the settlement or settlement group in question.

Regional Statistics, Vol 5, No 2. 2015: 62-81; DOI: 10.15196/RS05204 
the criteria both in 2001 and 2011, and Százhalombatta in 2001. In 2011, Bonyhád, Hatvan, Kazincbarcika, and Körmend could also be separated from the hinterland of the nearby large towns. Accordingly, we designated 141 centres or centre-pairs in 2001 and 123 in 2011.

- Although the methodology required that the delimitation of centres should be able to manage the spatial heterogeneity of the country's settlements (employment centres of different sizes, labour movement of different intensity), catchment areas within catchment areas cannot be displayed with the method applied. Therefore, corrections described in the third point were necessary to manage very extreme cases. We think that the examination of the remaining secondary catchment areas, especially in the capital region, is justified, but their detailed presentation is not possible due to the limited size of the study. The method applied could not really handle the self-employing settlements either, as it is also shown by a few examples in the study.

When creating catchment areas around centres:

- On the one hand, irrespective of the intensity of attraction, we determined (and assigned to the selected centre) the settlements where the most important destination of commuting of employees was the central settlement in question.

- We merged centres strongly linked to another centre (that is, from where more than $10 \%$ of employees commuted to the centre in question) and brought their entire catchment area determined with a similar method.

- Finally, further settlements were assigned (indirectly) to the designated centres according to the affiliation of their most important centre of attraction.

- The spatial continuity of catchment areas was formed in this way, because of which some settlements were re-assigned to the secondary or tertiary centre of attraction (however, this was not applied in case of the catchment area of Miskolc).

The number of the established, employment-based urban regions decreased between 2001 and 2011: the decrease in the number of centres and the fact that several more important actors got in the shadow of a nearby larger town show the increasing importance of commuting and the development of broader units instead of more fragmented structures. Some centres drop out of the system due to the following reasons: first, there may be a decrease in the number of people employed there under 1,000; second, the settlements forming the catchment area turn to other centres; third, it could be the result of the strengthening commuting links to the nearby larger town (over 10\%), or, it may come from the combination of these factors. According to our investigation, a total of 31 centres dropped out of the system due to the abovementioned reasons, which can be mostly explained by the increasing importance of commuting to a nearby (larger) centre. Among them, there are such towns of considerable size, such as Cegléd, Hajdúszoboszló, or Törökszentmiklós (Table 2). There are also settlements that became centres by 2011:

Regional Statistics, Vol 5, No 2. 2015: 62-81; DOI: 10.15196/RS05204 
in most cases, the number of people employed locally increased above 1,000 there. However, in the Great Plain, several centres entered the system by creating new catchment areas. The case of Hatvan is interesting: despite the fact that more than $10 \%$ of employees commuted from there, it was separated from the Budapest urban region in 2011 because the number of people employed there locally increased so that the daily labour force account of the town became positive (Table 2).

Table 2

Labour market catchment centres entering and dropping out of the system according to delimitations in 2001 and 2011

\begin{tabular}{|c|c|c|}
\hline $\begin{array}{l}\text { Main reason for } \\
\text { the change }\end{array}$ & $\begin{array}{l}\text { Entering } \\
\text { the system }\end{array}$ & $\begin{array}{l}\text { Dropping out of } \\
\text { the system }\end{array}$ \\
\hline $\begin{array}{l}\text { Number of persons } \\
\text { employed locally } \\
\text { increased to more } \\
\text { than / decreased to } \\
\text { less than } 1,000\end{array}$ & $\begin{array}{l}\text { Abádszalók, Abaújszántó, } \\
\text { Kál, Nyírmada, Szany, } \\
\text { Szendrô; }\end{array}$ & $\begin{array}{l}\text { Beled, Beremend, Bugac, } \\
\text { Bükkábrány, Nagyoroszi, } \\
\text { Sásd; }\end{array}$ \\
\hline $\begin{array}{l}\text { Acquiring attracted } \\
\text { settlement / losing } \\
\text { attracted settlements }\end{array}$ & $\begin{array}{l}\text { Battonya, Harta, Kecel, } \\
\text { Kunszentmiklós; }\end{array}$ & $\begin{array}{l}\text { Balkány, Bercel, } \\
\text { Jászfényszaru, Mezőhegyes, } \\
\text { Mezőtúr, Nagyigmánd, } \\
\text { Putnok, Százhalombatta, } \\
\text { Vésztő; }\end{array}$ \\
\hline $\begin{array}{l}\text { Commuting from the } \\
\text { settlement decreased } \\
\text { under /increased } \\
\text { above } 10 \%\end{array}$ & Kisbér, Sellye; & $\begin{array}{l}\text { Bábolna, Balatonkenese, Bük, } \\
\text { Cegléd, Edelény, } \\
\text { Hajdúszoboszló, Kaba, } \\
\text { Lábatlan, Martfú, Siklós- } \\
\text { Harkány, Simontornya, } \\
\text { Szécsény, Tiszalök, Tompa, } \\
\text { Törökszentmiklós, } \\
\text { Zalaszentgrót; }\end{array}$ \\
\hline $\begin{array}{l}\text { Positive labour force } \\
\text { account }\end{array}$ & Hatvan; & 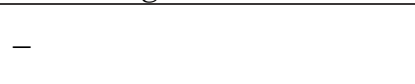 \\
\hline
\end{tabular}

The attribute most closely linked to the centres is the volume of local employment. Between 2001 and 2011, the change in the absolute weight of employment centres shows a typical regional pattern (Table 3). Budapest and settlements around the capital that are not independent centres (Budaörs, Szigetszentmiklós, Dunakeszi, Vecsés, and Gyál), the largest county seats in the Great Plain (Debrecen, Szeged, Nyíregyháza, and Kecskemét), and some re-forming centres along the industrial axis (Kozma 1998) (Tatabánya, Komárom, and Zalaegerszeg on the West and Hatvan and Tiszaújváros on the East) appeared among the biggest winners. At the same time, the growth in the number of people employed locally results not only from the change in the economic performance, but also the impact of public employment which was already considerable at the time of the 2011 census. The group of the biggest losers

Regional Statistics, Vol 5, No 2. 2015: 62-81; DOI: 10.15196/RS05204 
of the decade is also heterogeneous. Traditional heavy industry settlements (Salgótarján, Dunaújváros, as well as Balatonfüzfő, Pusztavám, and Visonta which are not included among centres), centres exposed to the crisis in the light industry (Baja and Körmend), some representatives of the re-industrialization in the 1990s that were less dynamic after the turn of the millennium (Székesfehérvár, Sárvár, and Szombathely), as well as employers with logistical function (Záhony and Taszár which is not a centre) appeared in this range (Table 3).

Table 3

Settlements showing the largest absolute change in the number of people employed locally between 2001 and 2011

\begin{tabular}{l|l}
\hline \multicolumn{1}{c|}{ Largest growth } & Largest decline \\
\hline Budapest $(+60,833)$ & Salgótarján $(-3,493)$ \\
Debrecen $(+9,927)$ & Dunaújváros $(-2,907)$ \\
Szeged $(+7,939)$ & Székesfehérvár $(-2,817)$ \\
Nyíregyháza $(+7,549)$ & Sárvár $(-1,708)$ \\
Kecskemét $(+7,193)$ & Balatonfü̊fó" $(-1,515)$ \\
Budaörs $(+7,066)$ & Nagykanizsa $(-1,383)$ \\
Sqigetszentmiklós $(+5,208)$ & Szombathely $(-1,277)$ \\
Tiszaújváros $(+5,163)$ & Szécsény $(-1,214)$ \\
Dunakeszi $(+3,912)$ & Baja $(-1,182)$ \\
Hatvan $(+3,729)$ & Visonta $(-1,138)$ \\
Tatabánya $(+3,668)$ & Pusztavám $(-1,129)$ \\
Vecsés $(+3,376)$ & Taszár $(-1,090)$ \\
Gyál $(+3,360)$ & Záhony $(-1,081)$ \\
Zalaegerszeg $(+3,332)$ & Körmend $(-1,040)$ \\
Komárom $(+3,094)$ &
\end{tabular}

Note: Was not a centre at either date - italics. Became a centre / ceased to be a centre - bold.

The decrease in the number of local labour systems also resulted in an increase in average sizes of the units, which is reflected in the number of settlements and in the number of employees as well (Table 4). After Budapest, units integrating the largest number (more than 100) of settlements were Pécs, Miskolc, Zalaegerszeg, and Győr, both in 2001 and 2011. Except for Győr, it can be stated about all of the three rural regions that the relative importance of the centres is coupled with a fragmented settlement structure and with the lack/weakness of alternative centres. The latter can be seen well in the considerable growth in the catchment area of all the three towns: Miskolc 'swallowed up' the district of Edelény, Pécs, Siklós-Harkány, Zalaegerszeg, and Zalaszentgrót between the two dates. In respect of the volume of employment, a different picture is outlined that arises from the differences in settlement geography. The district of Budapest was followed by Debrecen, Székesfehérvár, and Győr, and 
by the districts of other regional centres (Miskolc, Pécs, and Szeged). In all of the listed regions, employment was over 90 thousand persons in 2001, and over 100 thousand in 2011 (half of the county's area). At the same time, their order changed due to their different dynamics that result from the actual increase in their employment and the horizontal extension of their catchment areas. Debrecen strengthened its second place by integrating Hajdúszoboszló and Kaba, Miskolc moved forward to the third place, and Győr overtook Székesfehérvár by 2011.

Table 4

\section{Some major characteristics of Local Labour Systems}

\begin{tabular}{l|r|r}
\hline \multicolumn{1}{c|}{ Characteristics } & 2001 & 2011 \\
\hline Pieces & 141 & 123 \\
Average number of settlements & 22 & 26 \\
Maximum number of settlements & 209 & 213 \\
Minimum number of settlements & 2 & $\mathbf{3 0 , 1 2 6}$ \\
Average number of people employed & $\mathbf{2 4 , 8 4 1}$ & \\
locally & & $1,252,180$ \\
Maximum number of people employed & $1,115,396$ & 1,241 \\
locally & 1,113 & $\mathbf{6 5}$ \\
Minimum number of people employed & & \\
locally & $\mathbf{5 5}$ & 109 \\
Average intensity (people commuting & & \\
from and to the settlement together & & \\
as a percentage of all employees) & 120 & 30 \\
Maximum intensity (people commuting & & $\mathbf{6 9}$ \\
from and to the settlement together & & 99 \\
as a percentage of all employees) & 19 & 34 \\
Minimum intensity (people commuting & $\mathbf{7 2}$ & \\
from and to the settlement together & 98 & \\
as a percentage of all employees) & 38 & \\
Weight of the centre (average, \%) & & \\
Weight of the centre (maximum, \%) & & \\
Weight of the centre (minimum, \%) & &
\end{tabular}

Smaller units that represent a fragmented structure were characteristic in regions having marked small centres farther away from larger centres, as well as in the inner and outer peripheries of the Great Plain, which are more closed in respect of labour movement between settlements and have fewer centres with more significant scope (were mostly located in the territory between the inner and outer town ring). While, for example, the territory of Pest county was basically shared by two regions, the centre of Budapest and the centre of Vác, and in Fejér county three centres (Székesfehérvár, Dunaújváros, and Mór) dominated the area, the territory of BácsKiskun county was divided among fourteen units in 2011 (Figures 3-4). The general

Regional Statistics, Vol 5, No 2. 2015: 62-81; DOI: 10.15196/RS05204 
increase in the importance of commuting and the trend between the two censuses points towards the disappearance of micro-regions at national level: in 2001 84 districts with less than 10 thousand people and 45 districts with less than 5 thousand people were delimitated, while in 2011, these figures were only 63 and 37, respectively. In particular, the proportion of employees in local labour systems with more than 100 thousand people and in those with 10-20 thousand people showed an increasing trend, mostly at the expense of lower categories (Table 5).

\section{Distribution of settlements and people employed locally by the magnitude of the Local Labour Systems}

\begin{tabular}{c|c|c|c|c}
\hline \multirow{2}{*}{$\begin{array}{c}\text { LLS-categories by } \\
\text { the number of people } \\
\text { employed locally }\end{array}$} & \multicolumn{2}{|c|}{$\begin{array}{c}\text { Number of Local Labour } \\
\text { Systems in the categories }\end{array}$} & \multicolumn{2}{|c}{$\begin{array}{c}\text { Share in the number of people } \\
\text { employed locally, \% }\end{array}$} \\
\cline { 2 - 5 } & 2001 & 2011 & 2001 & 2011 \\
\hline $1,000,000-$ & 1 & 1 & 31.8 & 33.8 \\
$100,000-999,999$ & 3 & 6 & 9.6 & 18.3 \\
$50,000-99,999$ & 9 & 8 & 18.8 & 14.3 \\
$20,000-49,999$ & 18 & 16 & 17.0 & 13.8 \\
$10,000-19,999$ & 26 & 29 & 10.9 & 11.5 \\
$1,000-9,999$ & 84 & 63 & 11,9 & 8,2 \\
\hline Total & 141 & 123 & 100.0 & 100.0
\end{tabular}

\section{Local Labour Systems in 2001}

Table 5

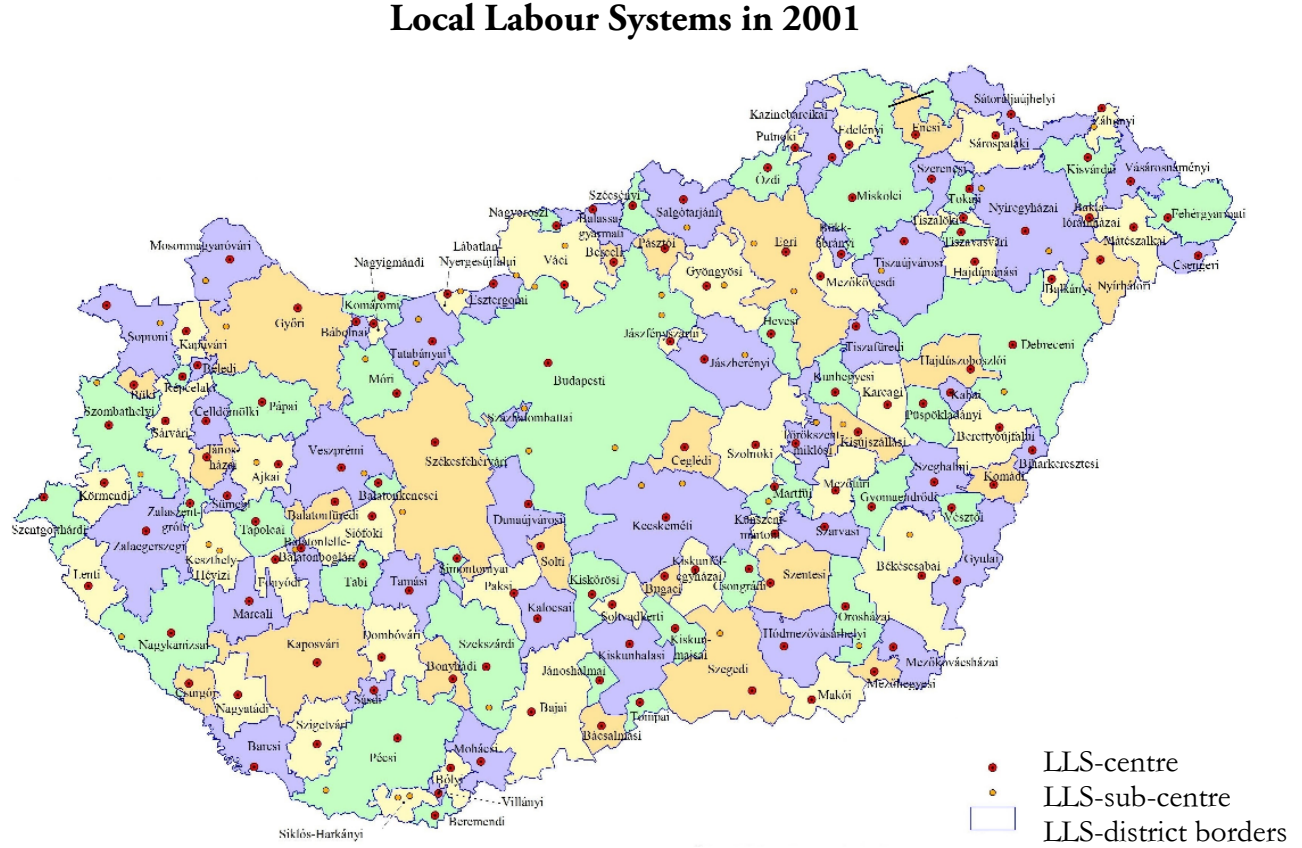

Regional Statistics, Vol 5, No 2. 2015: 62-81; DOI: 10.15196/RS05204 


\section{Local Labour Systems in 2011}

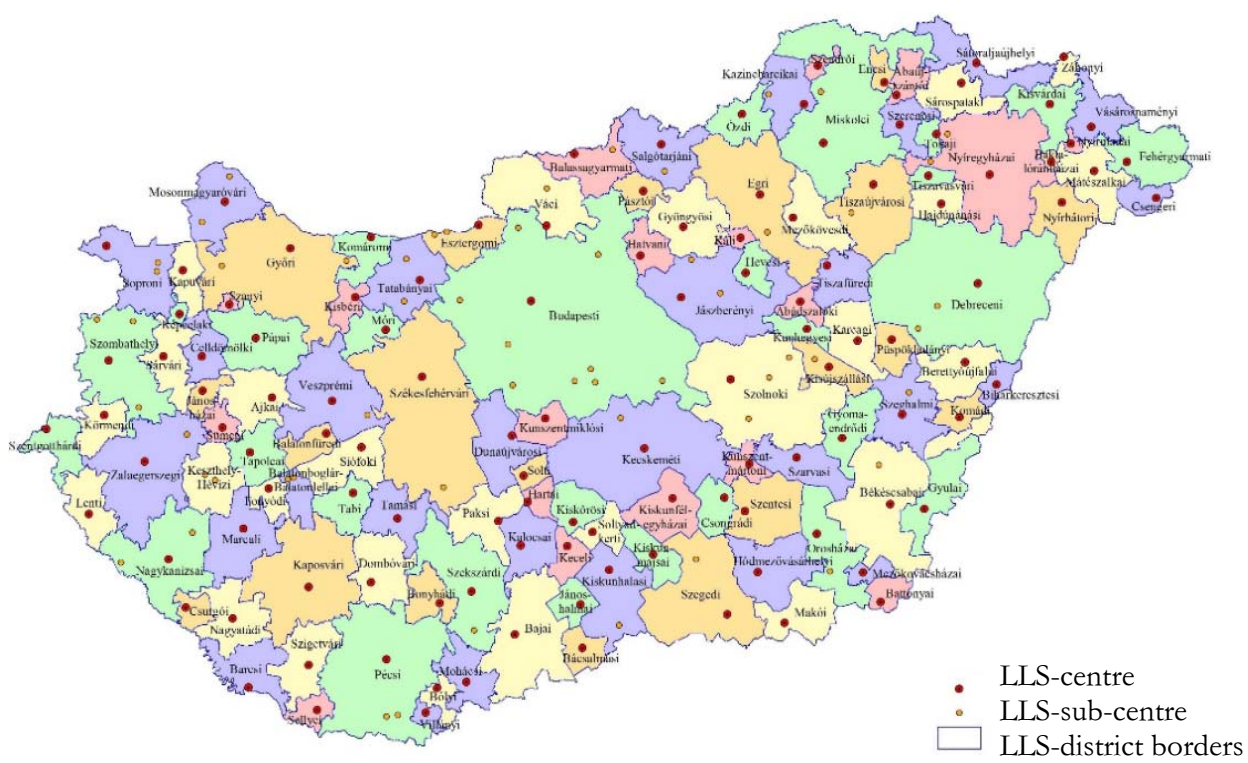

The strengthening commuting can be demonstrated by the increasing intensity of labour movement as well (Table 4). At the same time, there are huge differences among regions delimitated: while in the regions of Záhony, Jánosháza, and Mór, the total number of those commuting from and to as a percentage of all employees approached or exceeded $100 \%$ on both dates, the indicator was less than $45 \%$ in 38 regions (37 in the Great Plain) in 2001 and in 13 regions (in the Great Plain) in 2011. The former phenomenon can be associated with the relatively small size of marked employment centres and the fragmented settlement structure of their environment (that is, the considerable separation of place of residence and place of work), while the latter one reflects the more closed labour market and self-employing nature of settlements in the Great Plain. The increase of local labour systems by absorbing smaller districts resulted in many cases of the decline of the centre's weight and the development of units having more sub-centres. In addition to regions around the two centre-pairs (Balatonboglár-Balatonlelle and Keszthely-Hévíz), such units developed around several larger employers as well: the weight of Tatabánya in its own district - in respect of people employed locally - was only $55 \%$ in both years, which reflects the significant role of Tata and Oroszlány as sub-centres. By integrating the subsystems of Martfü, Mezőtúr, and Törökszentmiklós, the region of Szolnok also increased significantly by 2011. Along with this, the weight of the county seat fell under 55\%. The differences in the cohesive centripetal forces in the two regions are demonstrated by the different data of commuting intensity: the value of the examined indicator was $75 \%$ in the region of Tatabánya and 60\% in the region of Szolnok (in

Regional Statistics, Vol 5, No 2. 2015: 62-81; DOI: 10.15196/RS05204 
the latter case, Mezőtúr was assigned to Szolnok as its most important centre of attraction not due to the intensity of attraction, but the absence of a centre of attraction in Szolnok).

Out of the more significant centres, the weights of Gyöngyös, Esztergom, and Mór (due to the effect of Visonta, Dorog, and Kisbér/Pusztavám) were relatively smaller in their own regions in 2001, and similar centres were Esztergom (due to Dorog, Nyergesújfalu, and Lábatlan) and Jászberény (because of the significance of the sub-centres in the Jászság) in 2011. The latter is also interesting because by 2011, the local labour system of Jászberény, preceding Sopron, Dunaújváros and Nagykanizsa, became the largest non-county seat employing unit. In addition to the districts of Tatabánya and Szolnok, several other county seats integrated settlements employing more than 5,000 people as well (Székesfehérvár-Várpalota, Pécs-Komló, and Békéscsaba-Békés in both years and Debrecen-HajdúböszörményHajdúszoboszló in 2011). Between 2001 and 2011, after Budaörs, Gödöllő, Érd, Dunakeszi, Szigetszentmiklós, Szentendre, Vecsés, Dunaharaszti, Törökbálint, Gyál, Dabas, Veresegyház, Fót and Biatorbágy, Budapest integrated Cegléd and Százhalombatta but lost Hatvan, which shows one of the largest increases in employment.

\section{Conclusions}

Our aim was to delimitate local labour systems, which is a dimension of functional urban areas, built on the commuting data of the 2001 and 2011 census on the basis of a methodology from the existing literature. In the course of the delimitation, we determine the units flexibly and cover the entire territory of the country without duplication. Our goal was to detect the changes between the two dates as well.

At both of the examined dates, local labour systems of very different sizes developed from micro-regions to units integrating almost the entire area of the county. In addition to the absolute size and the dynamics of the centres, the specific features of the settlement network, such as the lack of dominant centres in the periphery, also greatly influenced their formation.

The number of local labour systems decreased and their average size increased between the two dates, which is associated with less micro-regions mainly due to the increasing intensity of inter-municipal relations.

The peripheral features appear in the system in two ways: on the one hand, in the far-extending effects of some centres of attraction in space and, on the other hand, in the strongly local catchment areas of small centres, which are farther away from larger centres (linked only a little to them) and are not able to integrate larger areas.

The qualitative transformation of local labour systems is indicated by the increasing intensity of labour movement typical in numerous places on the one hand, 
and on the other hand, by the trend of growing number of sub-centres by the involvement of larger employers in many cases.

In our opinion, the delimitation of local labour systems is an important aspect of regional investigations. Of course, it cannot be considered as an alternative for the system of districts or micro-regions, as it is based only on employment relations and reflects their dynamically changing image. However, this is precisely the reason why it is worth taking the results of the delimitation into account in the analysis of labour market trends and in the efforts of expanding employment and their territorial scope. This limitation also offers an opportunity to carry out comparative examinations of more countries (beginning with the neighbouring countries of Hungary) on the basis of an equal territorial division, which would contribute to the more adequate exploration of Central European regional processes.

\section{Acknowledgement}

This research was supported by the European Union and the State of Hungary, co-financed by the European Social Fund in the framework of TÁMOP 4.2.4. A/2-11-1-2012-0001 'National Excellence Program'.

\section{REFERENCES}

Antikainen, J. (2005): The Concept of Functional Urban Area. Findings of the EPSON project 1.1.1. Informationen zur Raumentwicklung (7): 447-452.

BALCSÓK, I. (2000): Hátrányos helyzetű társadalmi rétegek az Északkelet-Alföld határ menti térségeinek munkaerôpiacán Tér és Társadalom 14 (2-3): 285-294.

BALCSÓK, I. - KONCZ, G. (2004): A Hajdú-Bihar megyei városok foglalkoztatási belyzetének alakulása a rendszerváltástól napjainkig. In: A versenyképesség regionális, vállalati és intézményi dimenziói. Győr. Fiatal regionalisták IV. országos konferenciájának CD kiadványa

BARANCSUK, Á. - GYAPAY, B. - SzALKAI, G. (2013): Az alsó középszintű térfelosztás elméleti és gyakorlati lehetőségei Területi Statisztika 53 (2): 107-129.

BELuszKY, P. (1967): A magyarorsqági városok vonzáskörz̨etei Kandidátusi Értekezés Tézisei. Debrecen. KLTE.

Beluszky, P. - SikOs T., T. (szerk.) (1982): Területi kutatások 5. MTA Földrajztudományi Kutatóintézet, Budapest.

BEluszky, P. - SikOS T., T. (2007): Változó falvaink MTA Stratégiai Tanulmányok Sorozat, Budapest.

BIHARI, Zs. - KOVÁCS, K. (2006): Lejtôk és csúszdák, avagy a foglalkoztatási esélyek térbeli egyenlőtlensége az ezredfordulón Tér és Társadalom 20 (4): 49-66.

BODOR, N. - PÉNZES, J. (2012): Eger komplex vonzáskörzetének dinamikai vizsgálata Tér és Társadalom 26 (3): 30-47.

BujDosó, Z. (2009): A megyehatár hatása a városok vonzáskörzetére Hajdú-Bihar megye példáján Studia Geographica 24. Debreceni Egyetemi Kiadó, Debrecen.

Regional Statistics, Vol 5, No 2. 2015: 62-81; DOI: 10.15196/RS05204 
Cörvers, F. - Hensen, M. - Bongaerts, D. (2009): Delimitation and Coherence of Functional and Administrative Regions Regional Studies 43 (1): 19-31.

DÖVÉNYI, Z. (1977): A vonzáskörzetek történeti kialakulásának és változásának vizsgálati lehetőségeiről Alföldi Tanulmányok 1: 132-142.

Drobne, S. - Konjar, M. - Lisec, A. - Pichler Milanović, N. - Zavodnik LamovšEK, A. (2010): Functional Regions Defined by Urban Centres of (Inter)National Importance - The Case of Slovenia. In: Schrenk, M. - Popovich, V. V. - Zeile, P. (eds.): Cities for Everyone. Liveable, Healthy, Prosperous. Promising Vision or Unrealistic Fantasy? Real Corp 2010 15th International Conference on Urban Planning, Regional Planning and Information Society. pp. 295-304., CORP - Competence Center of Urban and Regional Planning, Wien.

ERDősI, F. (1985): Az ingázás területi-vonzáskörzeti szerkezete Magyarországon Demográfia 28 (4): 489-498.

EU (2011): Cities of Tomorrow. Challenges, Visions, Ways Forward. European Union Regional Policy, Brussels.

FALUVÉGI, A. (2008): A foglalkoztatás területi-települési szerkezete Magyarországon Statisztikai Szemle 86 (12): 1077-1102.

FORRAY R., K. - HÍvES, T. (2009): Az iskolázottság, a foglalkoztatottság és az ingázás területi összefüggései Szociológiai Szemle 19 (2): 42-59.

HAjDú, Z. (2001): Magyarország közigazgatási földrajza Dialóg Campus Kiadó, Budapest-Pécs.

KARLSSON, C. - OlsSON, M. (2006): The Identification of Functional Regions: Theory, Methods, and Applications The Annals of Regional Science 40 (1): 1-18.

KERTESI, G. (2000): Ingázás a falusi Magyarországon - egy megoldatlan probléma Közgazdasági Szemle 47 (10):775-798.

Kertesi, G. - KÖLLŐ, J. (1998): Regionális munkanélküliség és bérek az átmenet éveiben. A bérszerkezet átalakulása Magyarországon II. rész Közgazdasági S zemle 45 (7-8): 621-652.

KESERÜ, I. (2013): Post-suburban transformation in the functional urban region of Budapest in the context of changing commuting patterns. PhD doktori disszertáció, SZTE TTIK, Szeged.

KISS, É. (2011): A válság területi konzekvenciái az iparban Területi Statisztika 51 (2): 161-180.

KlapkA, P. - Halás, M. - Tonev, P. (2013): Functional Regions: Concept and Types In: 16th International Colloquim on Regional Science, Conference Proceedings (Valtice 19-21.6.2013). pp. 94-101., Masarykova Univerzita, Brno.

KovÁCs, K. (2010): Területi-társadalmi egyenlőtlenségek a rendszerváltozás utáni Magyarországon. In: Fábián, A. (szerk.): Párbeszéd és együttmüködés. Területfejlesztési Szabadegyetem 2006-2010. pp. 15-32., Nyugat-Magyarországi Egyetem Kiadó, Sopron.

KozMA, G. (1998): A gazdasági élet szereplőinek térbeli preferenciái Falu Város Régió 5 (9): 7-14.

LACKÓ, L. - ENYEDI, GY. - KőSZEgFAlVI, GY. (1978): Functional Urban Regions in Hungary Studia Geographica 24. International Institute for Applied Systems Analysis, Laxenburg.

MENDÖL, T. (1963): Altalános településföldrajz Akadémiai Kiadó, Budapest.

MOLNÁR, E. - PÉNZES, J. (2005): Kis- és középvárosi foglalkoztatási centrumok az Északalföldi Régióban In: Czimre Klára (szerk.): Kisközségtól az Eurorégióig. Prof. Dr. Süli-

Regional Statistics, Vol 5, No 2. 2015: 62-81; DOI: 10.15196/RS05204 
Zakar István tiszteletére szerzett tanulmányok gyűjteménye pp. 159-175., Didakt Kft. , Debrecen.

NAGY, R. (1988): Szolnok város vonzásviszonyai (1949-1980) Alföldi Tanulmányok 12: 219-236.

OECD (2002): Redefining Territories. The Functional Regions Organization for Economic Co-operation and Development, Paris.

OECD (2012): Defining “Urban”. A New Way to Measure Metropolitan Areas Organization for Economic Co-operation and Development, Paris.

PÁszTOR, I. Z. - PÉNZES, J. (2012): Foglalkoztatási krízis és jövedelmi periférizálódás Északkelet-Magyarországon a roma népesség arányainak tükrében Területi Statisztika 52 (4): 353-371.

PÉNZES, J. (2013): A foglalkoztatottság, az ingázás és a jövedelmi szint összefüggései Északkelet- és Északnyugat-Magyarországon Területi Statisztika 53 (3): 202-224.

RADVÁNSZKI, Á. - SÜTŐ, A. (2007): Hol a határ? Helyi munkaerôpiaci rendszerek Magyarországon - Egy közép-európai transznacionális projekt újdonságai a hazai településpolitika számára Falu Város Régió 14 (3): 45-54.

SÜLI-ZAKAR, I. (2010): A régió: földrajzi integráció. In: Süli-Zakar, I. (szerk.): A terület- és településfejlesztés alapjai II. pp. 145-155., Dialóg-Campus Kiadó, Budapest-Pécs.

SÜTŐ, A. (2008): Város és vidéke rendszerek és típusaik Magyarországon Falu Város Régió 15 (3): 51-64.

SzABÓ, P. (1998): A napi ingázás kérdésköre a kilencvenes években Magyarországon Tér és Társadalom 12 (4): 69-89.

SZALKAI, G. (2010): Várostérségek lehatárolása a közúti forgalom nagysága alapján a magyar határok mentén Tér és Társadalom 24 (4): 161-184.

SzALKAI, G. (2012): A járások kialakításának módszertani megalapozása Területi Statisztika 52 (3): 215-229.

TiMÁR, J. (1983): Vonzáskörzet-vizsgálatok Szarvas és Gyoma térségében Alföldi Tanulmányok 5: 231-254.

TÓTH, G. (2013/a): Az elérhetöség és alkalmazása a regionális vizsgálatokban Központi Statisztikai Hivatal, Budapest.

TóTH, G. (2013/b): Bevez̨etés a területi elemzések módszertanába Miskolci Egyetem, Miskolc.

\section{DATA SOURCES}

http://www.ksh.hu/nepszamlalas/docs/modszertan.pdf

Regional Statistics, Vol 5, No 2. 2015: 62-81; DOI: 10.15196/RS05204 